\title{
Aryl Hydrocarbon Receptor
}

National Cancer Institute

\section{Source}

National Cancer Institute. Aryl Hydrocarbon Receptor. NCI Thesaurus. Code C17273.

Aryl hydrocarbon receptor ( $848 \mathrm{aa}, \sim 96 \mathrm{kDa}$ ) is encoded by the human AHR gene. This protein is involved in the regulation of apotosis, the cell cycle and xenobiotic-stimulated gene transcription. 